\title{
Massive proliferation of Grateloupia intestinalis (Hooker fil. et Harvey) Setchell ex Parkinson (Rhodophyta, Halymeniaceae), a non-native species in Valparaíso Bay, central Chile
}

\author{
Proliferación masiva de Grateloupia intestinalis (Hooker fil. et Harvey) Setchell ex Parkinson \\ (Rhodophyta, Halymeniaceae), especie no-nativa en la bahía de Valparaíso, Chile central \\ Gloria Collantes ${ }^{1}$ and Pilar Muñoz-Muga ${ }^{1}$ \\ ${ }^{1}$ Facultad de Ciencias del Mar y de Recursos Naturales, Universidad de Valparaíso, Valparaíso, \\ Casilla 5080, Reñaca, Viña del Mar, Chile \\ gloria.collantes@uv.cl
}

\begin{abstract}
Resumen.- Se informa la proliferación masiva de Grateloupia intestinalis, una especie no reportada previamente en la bahía de Valparaíso, Chile. Un total de 74 ejemplares fueron recolectados al azar en el intermareal bajo de Playa Cochoa (32 $\left.57^{\prime} 21,8^{\prime \prime} \mathrm{S}-71^{\circ} 32^{\prime} 57,7^{\prime \prime} \mathrm{W}\right)$ en octubre de 2006. El material fue herborizado y se realizaron cortes histológicos para su observación con microscopía óptica. Los especimenes recolectados se caracterizan por un talo de color rojo vinoso, linear, ligulado, con uno o dos ápices, ligeramente gelatinoso y ondulado. Los especimenes alcanzan aproximadamente 18 $\mathrm{cm}$ de largo y $1 \mathrm{~cm}$ de ancho. Los cortes transversales muestran una corteza con tres a cuatro cubiertas de células elípticas entre
\end{abstract}

las cuales se presentaron tetrasporangios cruciados esparcidos. La médula es laxa dejando en el centro un espacio lleno de mucílago. No se observaron plantas cistocárpicas. En la costa de Chile central no ha sido registrada otra proliferación de $G$. intestinalis como la observada en Playa Cochoa. Aunque se había encontrado en el sur del país, esta información no era explícita por encontrarse en una publicación sobre Gigartinales y Rhodymeniales, en la cual esta especie sólo se menciona entre el material de herbario trabajado. Se sugiere que $G$. intestinalis sería una especie no nativa para la costa de Chile.

Palabras clave: Tetrasporangios, distribución geográfica, algas

\section{Introduction}

Eight species of Grateloupia C. Agardh have been listed in the catalogue of the benthic seaweeds of the Pacific southern temperate coast of Chile: G. denticulada, $G$. doryphora, G. filicina, G. rojassii, G. spathulata, G. subsimplex, G. versicolor and Grateloupia sp. (Ramírez \& Santelices 1991). Saunders et al. (2004) included G. intestinalis collected by A. Peters from Los Molinos, Valdivia, southern Chile, in a table that showed the collection data for the species included in their molecular analyses.

Due to their variable morphology, the species of the genus Grateloupia are difficult to determine (Ardré \& Gayral 1961, Cabioch et al. 1997, Kraft 1977). The species Grateloupia doryphora, described from Chile and Peru (Ramírez \& Santelices 1991) has long been viewed as introduced in the Atlantic Ocean as well in Western Europe (Farnham \& Irving 1973, Cabioch et al. 1997, Maggs \& Stegenga 1999), eastern North America (Villalard-Bohnsack \& Harlin 1997), and in the Mediterranean Sea (De Masi \& Gargiulo 1982, Tolomio 1993). Recently, on the basis of morphological and molecular evidence, Gavio \& Fredericq (2002) have clarified the taxonomic position of G. turuturu, the correct name species reported as G. doryphora. These last authors proposed a possible route of introduction of G. turuturu from its native Japan, while restricting the distribution of G. doryphora to Peru and Chile.

Understanding the mechanisms and impact of biological invasions is crucial to preserve marine biodiversity. The invading species can compete or hybridize with the native species, resulting in the loss of marine biodiversity and an altering of fundamental processes in the ecosystem (Vitousek et al. 1997). The invasion of coastal ecosystems by non-native species is a widely recognized phenomenon and it is expanding in scope (Grosholz \& Ruiz 1996). Although most of the introduced species do not become invasive, those that do can cause an enormous ecological and economic impact (Preskitt 2006 ${ }^{1}$ ).

${ }^{1}$ Preskitt L. 2006. Invasive Marine Algae of Hawaii. Department of Botany, University of Hawaii at Manoa. [on-line] <http:// www.hawaii.edu/reefalgae/invasive_algae/index.htm>. 


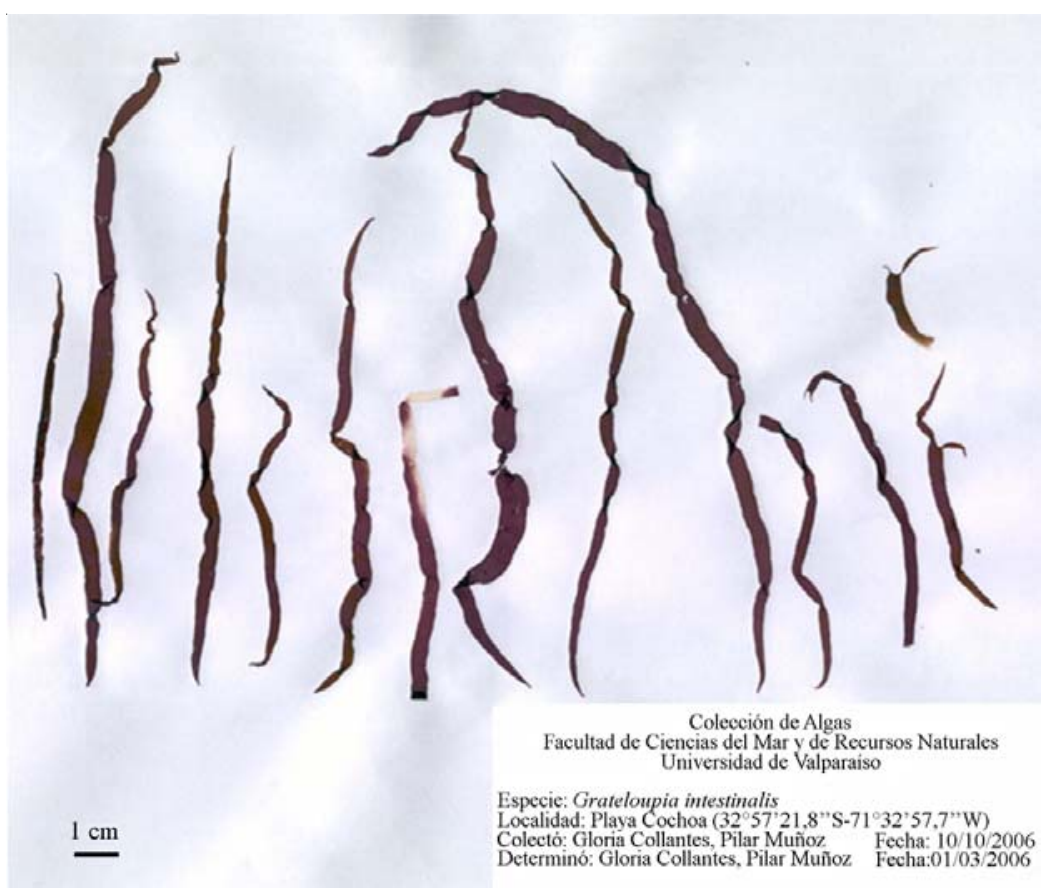

Figure 1

Grateloupia intestinalis. Habits of specimens used in this study (MHNV-al-0019R-2)

Grateloupia intestinalis. Hábitos de los especimenes utilizados en el presente estudio (MHNV-al-0019R-2)

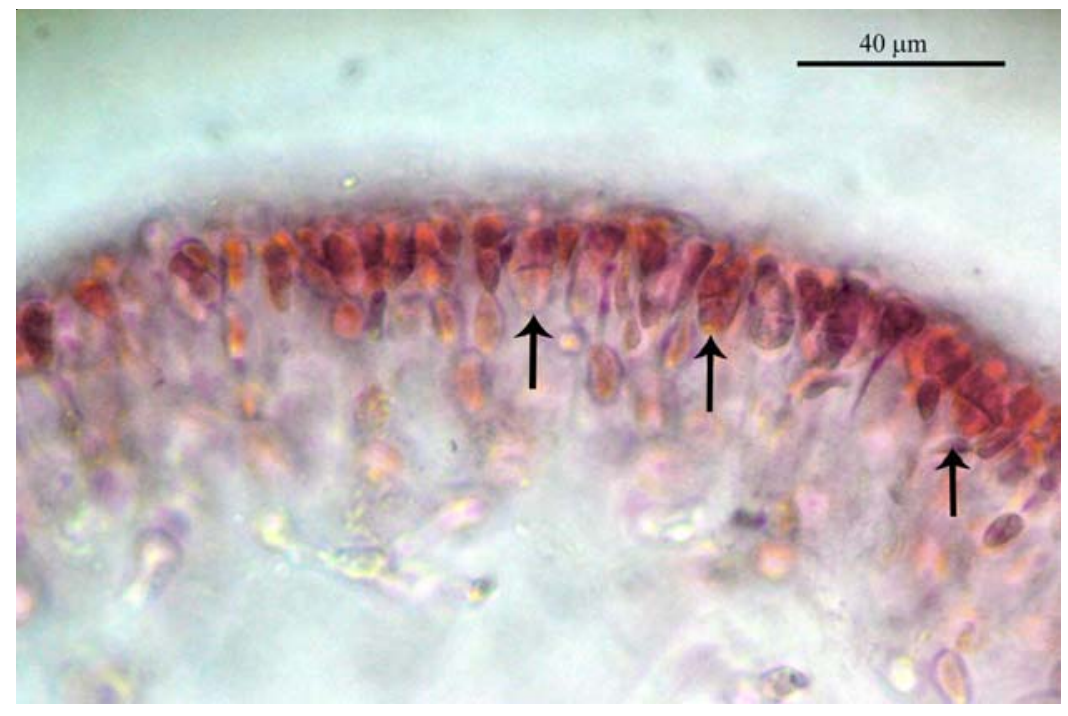

Figure 2

Grateloupia intestinalis from Playa Cochoa. Transverse section through a tetrasporophyte showing a lax medulla and three to four elliptical cortical cell layers. The arrows point to tetrasporangia

Grateloupia intestinalis de Playa Cochoa. Corte transversal a través de un tetrasporofito mostrando la médula laxa y tres a cuatro capas de células corticales elípticas. Las flechas apuntan a los tetrasporangios 
Recent publications have demonstrated that invasive species can be successfully identified on the basis of morphological characters. Early detection and handling of the foreign species have been the best tools to stop their impact on the coast of Hawaii (Abbott 1999). Five species of non-native seaweed invaders have been recognized from Chile; each species has been documented in the literature at least twice or has been collected at different time intervals. Among these five species of algae, two of them are highlighted: Mastocarpus papillatus and Codium fragile var. tomentosoides (Castilla et al. 2005). Nevertheless, only the green alga Codium fragile is considered a pest (Neill et al. 20032, Neill et al. 2006).

Mastocarpus papillatus, native to Japan, was first reported in Chile by Avila \& Alveal (1987). It is believed that this species most likely arrived in the area in the early 1980s on the hulls of ships associated with coal transport (Castilla et al. 2005). Codium fragile var. tomentosoides also native to Japan, was reported for the first time in Chile in 1998 by Neill et al. $\left(2003^{2}\right)$ as an invader in northern Chilean Gracilaria chilensis aquaculture facilities. Currently, $C$. fragile is found in 34 places between Antofagasta and Punta Arenas, with a discontinuous distribution and greater abundance in the north, in the region of Caldera, Calderilla and Bahía Inglesa. $C$. fragile alters the biodiversity and negatively affects the cultures of Gracilaria, with disastrous economic effects for the industry (Neill et al. 20032, Castilla et al. 2005, Neill et al. 2006). In this context the present work reports a non-native seaweed species of Grateloupia in Valparaiso Bay, Chile. It is improbable that this species was native to Valparaíso Bay because it has not been found before although the central coast of Chile has been the focus of enough seaweed collection efforts (Guiller 1952, Alveal 1970, Etcheverry 1986, Ramírez \& Santelices 1991, Hoffman \& Santelices 1997, Gonzáles \& Collantes 2001) including several thesis during the last two decades (González 1998, La Rosa 2003).

\section{Material and methods}

A total of 74 specimens were collected on October 10 , 2006 in the rocky intertidal of Playa Cochoa $\left(32^{\circ} 57^{\prime} 21,8^{\prime \prime} \mathrm{S}-71^{\circ} 32^{\prime} 57,7^{\prime \prime} \mathrm{W}\right)$ (GPS Garmin eTrex

\footnotetext{
${ }^{2}$ Neill P, O Alcalde \& J Correa. 2003. Presencia de la especie invasora Codium fragile (Chlorophyta) en el norte de Chile: efectos potenciales sobre cultivos de Gracilaria chilensis (Rhodophyta). XLVI Reunión Anual de la Sociedad de Biología de Chile, Pucón, Chile. Biological Research 36: 56 [Abstract].
}

Legend, datum WGS 84), Valparaíso, central Chile, and transferred wet to the laboratory. The material was vouchered according to traditional techniques and deposited in the Museo de Historia Natural de Valparaíso, voucher number MHNV-al-0019R-1, MHNV-al-0019R2. Algae were cross sectioned by hand with a razor blade. Microscopic observations were done with Nikon Labophot microscope, equipped with a digital camera Canon Power Shot A85. The vouchered specimens were scanned and registered using a HP ScanSet 3400Cs scanner. Vouchers were also dried in the field with silica gel for future molecular analyses.

Provisional determination of the species was carried out by comparing the collected material with the species descriptions of Grateloupia by Kützing (1867), De Toni (1905) and Kraft (1977).

\section{Results}

The collected specimens are characterized by red-wine linear, ligulate, gelatinous-fleshy, slightly undulated thalli, reaching up to $18 \mathrm{~cm}$ in length, $1 \mathrm{~cm}$ in width. The thalli reflect the light irregularly and have one or two apical regions, and are born on a short stipe (Fig. 1). Cross sections reveal a cortex $(60 \mu \mathrm{m})$ of 3-4 layers of elliptical cells between which cruciately divided tetrasporangia are interspersed (Fig. 2). The medulla is lax (100 $\mu \mathrm{m})$, medullary filaments separate and break apart, leaving the centre of the plant mostly hollow and filled with mucilage. The transition between cortex and medulla is abrupt. Habits of cystocarpic thalli have not been found.

\section{Discussion}

The external morphology and the construction of the medulla of Grateloupia individuals from Playa Cochoa (Fig. 1) show the centre of the plant mostly hollow and filled with mucilage, and do not agree with the description of any of the Grateloupia species previously reported for the Chilean coasts which have the centre of the plant filled with medulla without hollow (Ramírez \& Santelices 1991), but they display similar characteristics to those of Grateloupia intestinalis (Hooker fil. et Harvey) Setchell ex Parkinson, depicted in Figs. 1-21 by Kraft (1977).

The habits of Grateloupia collected in Playa Cochoa and G. intestinalis (Kraft 1977) differ in the range of the number of fronds that are simple in specimens from Playa Cochoa. These would correspond to specimens of a young population that became established no longer than four weeks earlier since during 2006 this beach was monthly monitored in search of Porphyra spp. and only few specimens of this species of Grateloupia had been previously observed. 


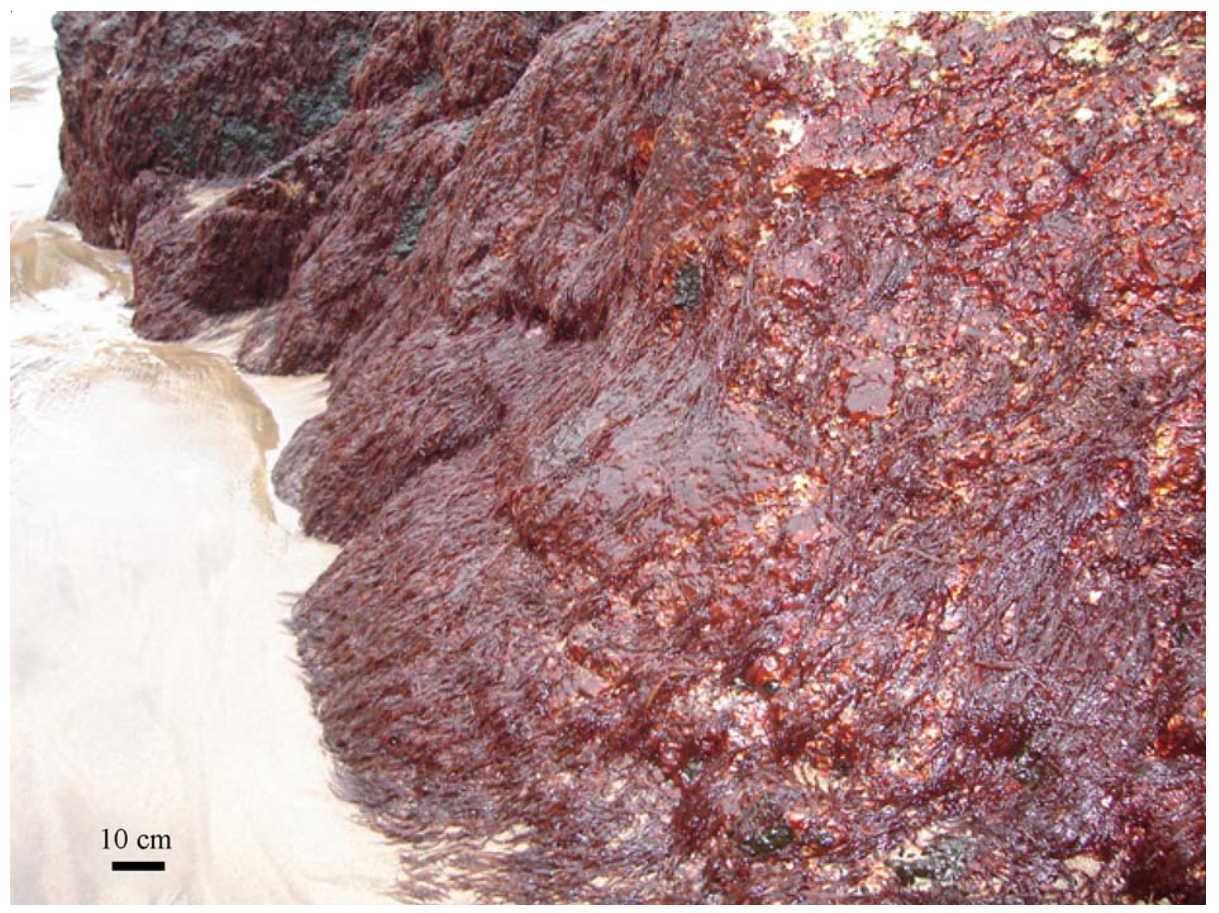

Figure 3

\section{Lower rocky intertidal zone exposed to the surge in Playa Cochoa showing the population of $G$ intestinalis}

Intermareal rocoso bajo de frente expuesto en Playa Cochoa mostrando la población de G. intestinalis

According to Guiry \& Guiry $\left(2008^{3}\right)$, G. intestinalis has as basionym and synonym Nemastoma intestinale Hooker \& Harvey 1855 ('intestinalis'). In the past, G. intestinalis had been confused with Grateloupia prolifera J. Agardh. Unfortunately specimens suitable for studies of cystocarp ontogeny have not been observed but Setchell (in herb. Lindauer) mentions that it has well developed pericarpia propria (i.e. Gonimocarps). The binomial Grateloupia intestinalis was never effectively published by Setchell (Chapman \& Parkinson 1974); its listing by Adams (1972) does not constitute valid publication under Art. 33 of the International Code of Botanical Nomenclature (fide Chapman \& Parkinson 1974).

The native distribution of $G$. intestinalis comprises New Zealand (Chapman \& Parkinson 1974, Womersley 1994, Adams 1994, Nelson \& Phillips 1996, Adams 1997, Miller 2005) and Tasmania (Womersley 1994).
A distance tree of results emphasizing Halymeniales (Saunders et al. 2004) showed that G. intestinalis collected by A. Peters on November 1996 from Los Molinos, Valdivia, Chile (voucher number: GWS000354; GenBank number: AY437702) solidly joined the two included species of Polyopes in all analyses and failed to join the generitype, G. filicina. Notwithstanding the Fig. 11 exhibited in Saunders et al. (2004) does not match the collection data, as the habit presented corresponds to G. intestinalis from New Zealand (Kraft 1977) and not to the specimen from Chile that they worked on.

In Playa Cochoa the population of G. intestinalis occurred in the semi - protected, lower rocky intertidal (Fig. 3), occupying almost completely the regular habitat of Porphyra pseudolinearis at the end of the winter and spring (González 1998, González \& Collantes 2001, La Rosa 2003, Muñoz-Muga 2005 $)$ and sharing rocks exposed to the surge with Codium dimorphum.

${ }^{3}$ Guiry MD \& GM Guiry. 2008. AlgaeBase. World-wide electronic publication, National University of Ireland, Galway. [on-line] $<$ http:// www.algaebase.org $>$.

${ }^{4}$ Muñoz-Muga P. 2005. Fenología morfológica y reproductiva del luchecillo Porphyra woolhousiae Harvey (Rhodophyta, Bangiophyceae). Seminario de Investigación de Biología Marina, Facultad de Ciencias del Mar, Universidad de Valparaíso, Valparaíso, 25 pp. 
In the central coast of Chile, such a proliferation of Grateloupia as the one seen in 2006 has not been registered in the subsequent years, only isolated specimens have been found in the area during winter, spring and the beginning of summer. G. intestinalis from Los Molinos, Valdivia, southern Chile, studied by Saunders et al. (2004), would be the first report of the species from Chilean coast.

The early and localized detection of the massive proliferation of G. intestinalis in Playa Cochoa represents a good model for the pursuit of the behavior of an introduced species in relation to the native species. The taxonomy of G. intestinalis from Playa Cochoa requires later confirmation of molecular and morphological evidence, as well as an interpretation of its possible routes of introduction.

\section{Acknowledgments}

We thank Dr. S. Fredericq for helpful suggestions to improve this manuscript and helped us to improve the first English version. We especially thank the anonymous reviewers for their constructive comments to the manuscript. This paper was funded by DIPUV 68-2007 and CIGREN, Universidad de Valparaíso.

\section{Literature cited}

Abbott IA. 1999. Marine red algae of the Hawaiian Islands, 477 pp. Bishop Museum Press, Honolulu.

Adams NM. 1994. Seaweeds of New Zealand. An Illustrated guide, 360 pp. Canterbury University Press, Christchurch.

Adams NM. 1997. Common seaweeds of New Zealand, 48 pp. Canterbury University Press, Christchurch.

Alveal K. 1970. Estudios ficoecológicos en la región costera de Valparaiso. Revista de Biología Marina 14(1): 7-88.

Ardré F \& P Gayral. 1961. Quelques Grateloupia de l'Atlantique et du Pacifique. Revue Algologique 6: 38-48.

Ávila M \& K Alveal. 1987. Ciclo de vida de Mastocarpus papillatus en el área de Concepción, Chile (Petrocelidaceae, Rhodophyta). Investigación Pesquera (Chile) 34: 129-138.

Cabioch J, A Castric-Fey, MT L'Hardy-Halos \& A Rio. 1997. Grateloupia doryphora, et Grateloupia filicina var. luxurians (Rhodophyta, Halymeniaceae) sur les cótes de la Bretagne. Cryptogamie Algologie 18: 117-137.

Castilla JC, M Uribe, N Bahamonde, M Clarke, $\mathbf{R}$ Desqueyroux-Faúndez, I Kong, H Moyano, N Rozbaczylo, B Santelices, C Valdovinos \& P Zavala. 2005. Down under the southeastern Pacific: marine non-indigenous species in Chile. Biological Invasions 7: 213-232.

Chapman VJ \& PG Parkinson. 1974. Cryptonemiales. In: Chapman VJ (ed). The marine algae of New Zealand. Part III. Rhodophyceae, pp. 155-278. J. Cramer, Lehre.
De Masi F \& \& GM Gargiulo. 1982. 'Grateloupia doryphora' (Mont.) Howe (Rhodophyta Cryptonemiales) en Mediterranée. Alliona 25: 105-108.

De Toni GB. 1905. Sylloge algarum. Florideae. Sectio IV: 1523-1973. Patavii, Padova.

Farnham WF \& LM Irving. 1973. The addition of a foliose species of Grateloupia to the British marine flora. British Phycology Journal 8: 208-209.

Gavio B \& S Fredericq. 2002. Grateloupia turuturu (Halymeniaceae, Rhodophyta) is the correct name of the non-native species in the Atlantic known as Grateloupia doryphora. European Journal of Phycology 37: 349-359.

González A. 1998. Caracterización de especies y/o morfotipos de Porphyra (Rhodophyta,Bangiales), 'luche' de las bahías Valparaíso y Laguna Verde, V Región, Chile. Tesis de Biología Marina, Instituto de Oceanología, Universidad de Valparaíso, Valparaíso, $150 \mathrm{pp}$.

González A \& G Collantes. 2001. Taxonomía numérica en la estimación de la diversidad de Porphyra spp. In: Alveal K \& T Antezana (eds). Sustentabilidad de la biodiversidad, pp. 125-138. Universidad de Concepción, Concepción.

Grosholz ED \& GM Ruiz. 1996. Predicting the impact of introduced marine species: Lessons from the multiple invasions of the European green crab Carcinus maenas. Biological Conservation 78: 59-66.

Guiller E. 1952. The intertidal ecology of the Montemar Area, Chile. Papers and Proceedings of the Royal Society of Tasmania 93: 165-183.

Hoffmann A \& B Santelices. 1997. Flora marina de Chile central, 434 pp. Ediciones Universidad Católica de Chile, Santiago.

Kraft GT. 1977. The morphology of Grateloupia intestinalis from New Zealand, with some thoughts on generic criteria within the family Cryptonemiaceae (Rhodophyta). Phycologia 16(1): 43-51.

Kützing FT. 1867. Tabulae Phycologicae, oder Abbildungen der Tange. Vol. XVII: 1-30, 100 pl. Gedruckt auf Kosten des Verfassers, Nordhausen.

La Rosa A. 2003. Monosporas en las historias de vida de especies de Porphyra de la bahía de Valparaíso. Tesis de Biología Marina, Facultad de Ciencias del Mar, Universidad de Valparaíso, Valparaíso, 83 pp.

Maggs CA \& H Stegenga. 1999. Red algal exotics on North Sea coasts. Helgoländer Meeresunters 52: 243-258.

Miller IJ. 2005. The structure of the polysaccharide from Grateloupia intestinalis in New Zealand. Botanica Marina 48: 142-147.

Neill PE, O Alcalde, S Faugeron, SA Navarrete, JA Correa. 2006. Invasion of Codium fragile spp. tomentosoides in northern Chile: A new threat for Gracilaria farming. Aquaculture 259: 202-210.

Nelson WA \& L Phillips. 1996. The Lindauer legacy: current names for the Algae Novae-Zelanicae Exsiccatae. New Zealand Journal of Botany 34: 553-582. 
Ramírez ME \& B Santelices. 1991. Catálogo de las algas marinas bentónicas de la costa temperada del Pacífico de Sudamérica, 437 pp. Monografías Biológicas 5, Pontificia Universidad Católica de Chile, Santiago.

Santelices B. 1989. Algas marinas de Chile, 399 pp. Ediciones Universidad Católica de Chile, Santiago.

Saunders GW, A Chiovitti \& GT Kraft. 2004. Small-subunit rDNA sequences from representatives of selected families of the Gigartinales and Rhodymeniales (Rhodophyta). 3. Delineating the Gigartinales sensu strict. Canadian Journal of Botany 82(1): 43-74.

Tolomio C. 1993. Prima segnalazione di Grateloupia doryphora (Mont) Howe (Rhodophyceae) nella Laguna di Venezia. Lavori della Società Veneziana di Scienze Naturali 18: $215-220$.
Villalard-Bohnsack M \& M Harlin. 1997. The appearance of Grateloupia doryphora (Halymeniaceae, Rhodophyta) on the Northeast coast of North America. Phycologia 40: 324-328.

Vitousek PM, CM D’Antonio, LL Loope, M Rejmanek \& R Westbrooks. 1997. Introduced species: a significant component of human-caused global change. New Zealand Journal of Ecology 21: 1-16.

Womersley HBS. 1994. The marine benthic flora of southern Australia - Part IIIA - Bangiophyceae and Florideophyceae (Acrochaetiales, Nemaliales, Gelidiales, Hildenbrandiales and Gigartinales sensu lato), 508 pp. Australian Biological Resources Study, Canberra.

Recibido el 28 de diciembre de 2008 y aceptado el 2 de junio de 2009 